\title{
Nutrition in Transition from Homo sapiens to Homo economicus
}

\author{
Ram B Singh ${ }^{1, *}$, Toru Takahashi ${ }^{2}$, Takashi Nakaoka ${ }^{3}$, Kuniaki Otsuka ${ }^{3}$, Eri Toda ${ }^{3}$, Hyun Ho Shin ${ }^{4}$, \\ Moon-Kyu Lee ${ }^{4}$, Vicky Beeharry ${ }^{5}$, Krisimira Hristova ${ }^{6}$, Jan Fedacko ${ }^{7}$, Daniel Pella ${ }^{7}$, Fabien De \\ Meester $^{8}$, Douglas W Wilson ${ }^{9}$, Lekh R Juneja ${ }^{10}$, Danik M. Martirosyan ${ }^{11,12}$ \\ ${ }^{1}$ Halberg Hospital and Research Institute, India \\ ${ }^{2}$ Graduate School of Human Environment Science, Fukuoka Women's University, Japan \\ ${ }^{3}$ Department of Internal Medicine, Tokyo Women's Medical University, Medical Center East, Tokyo, Japan \\ ${ }^{4}$ Korean Society of Lipidology and Atherosclerosis, Korea \\ ${ }^{5}$ Faculty of Medicine, Russian Peoples Friendship University, Moscow, Russia \\ ${ }^{6}$ University National Heart Hospital, Sofia, Bulgaria \\ ${ }^{7}$ Faculty of Medicine, PJ Safaric University, Kosice, Slovakia \\ ${ }^{8}$ The Tsim Tsoum Institute, Krakow, Poland \\ ${ }^{9}$ School of Medicine, Pharmacy and Health, Durham University, UK \\ ${ }^{10}$ Taiyo Kagaku Co. Ltd, Yokkaichi, Japan \\ ${ }^{11}$ Department of Internal Medicine, UT Southwestern Medical Center, Dallas, TX, USA \\ ${ }^{12}$ Functional Food Center, TX, USA
}

\begin{abstract}
The food and nutrient intake among Paleolithic Homo sapiens, hunter-gatherers and among Asian and Homo economicus Western populations shows marked variations. Economic development and affluence may be associated with a decrease in the consumption of omega- 3 fatty acids, vitamins, antioxidants and amino acids and significant increase in the intakes of carbohydrates, (mainly refined), fat (saturated, trans fat and linoleic acid) and salt compared to the Paleolithic period. The protein or amino acid intake was 2.5 fold greater (33 vs. 13\%) in the Paleolithic diet Homo sapiens compared to modern Western diet consumed by Homo economicus populations. Approximately 10,000 years ago, prior to the Agricultural Revolution, our diet was based on an enormous variety of wild plants. However, today about $17 \%$ of plant species provide $90 \%$ of the world's food supply which is mainly contributed by grains produced by fertilizer based on rapidly grown crops which may result in a decrease in nutrient density and increase in energy. Wheat, corn and rice account for three fourths of the world's grain production on which humans are dependent for their food supply. Grains are high in omega-6 fatty acids and carbohydrates and low in omega-3 fatty acids and antioxidants compared to leafy green vegetables. It has been estimated that diet of Homo sapiens was characterized by higher intakes by essential and nonessential amino acids, calcium, potassium, magnesium, flavonoids and w-3 fatty acids whereas modern Western diet of Homo economicus has excess of energy-rich refined carbohydrates, w-6, trans fat and saturated fat and low in protective nutrients. The consumption of such diets in wealthy countries in conjunction with sedentary behavior is associated with increased prevalence of morbidity and mortality due to noncommunicable diseases (NCDs).
\end{abstract}

Keywords: Diets, health behavior, wealth, foods, nutrients, cardiovascular diseases.

\section{INTRODUCTION}

Homo sapiens and its predecessors, namely Homo erectus and Homo habilis were primarily vegetarians according to Palæontological records. Consciousness of space and time

*Address correspondence to this author at the Halberg Hospital and Research Institute, Civil Lines, India; Tel/Fax: 00915912417437;

E-mail: rbs@tsimtsoum.net led to perspective and organization, and hunting groups developed gradually as man moved away from other primates and became skilled in tool making [1-3]. The modern man, Homo economicus, has evolved from his primate precursors as an even more skilled and organized hunter-gatherer [1-3]. Man started farming some 10,000 years ago, an adaptation which in turn led to unprecedented technical development, agriculture, industry and commerce. From that perspective, it seems that the biological function of most social groups is to 
trigger the what/when hunter-gatherers' anticipation, socially and physiologically [1-5]. The Paleolithic diet was about naturally available wild foods: fruits, vegetables, green leaves, seeds, honey, eggs, fish, and meat from running animals [5-10]. These foods were also available to pre-agricultural humans and obviously shaped modern man's genetic nutritional requirement. Early man like hunter-gatherers, also had excellent health characteris-tics; enormous physical activity with limited or no mental stress, alcoholism, and tobacco intake that are now important behavioral risk factors of noncommunicable diseases (NCDs).

It is the modern affluent society of the $20^{\text {th }}$ century in the Western World which added stress and started refining and processing of foods, storing and distributing them in the continuous search of a better economic model [10-14]. This modern pattern of food availability, in which Homo economicus has entered, willingly or not, i.e. production and marketing led by profit, translates into new unprecedented challenges, opportunities and threats, for mankind [14, 15]. Further proof to support this contention comes from a recent study that Americans die sooner, are least likely to reach the age of 50 years, and have higher rates of disease or injury [16]. Americans also may be less healthy from birth to 75 years of age than people in 16 other economically wealthy countries. It is surprising that this health disadvantage has been getting worse for 30 years, specially among women despite heavy spending of funds on health which is considered to be a big business in America [16]. It seems that there is globalization of wealth without much improvement in health attributes [17]. The Japanese and the Mediterranean traditional diets appear to share a common standard (omega$6 / 3 \sim 1 / 1$ ) with the Paleolithic diet, although diet and lifestyle in Japan have been under transition from poverty in the 1950s to affluence by the year 1980s, without increase in most NCDs.

\section{GENETIC VARIATIONS: FROM PALEOLITHIC TO NEOLITHIC REVOLUTION}

It is being increasingly recognized in the scientific literature, that the physical activity, sleep, sun exposure, and dietary needs of humans are genetically determined. The profound changes in the diet and lifestyle that occurred after the Neolithic Revolution, (first agricultural revolution; c12000 $\mathrm{BC}$ ), particularly after the Industrial Revolution, and the Modern Age, are too recent on an evolutionary time scale for the human genome to have fully adapted [2, 3, 7, 18-20]. Most of the human genome comprises genes selected during the Paleolithic period, despite various alleles being targets of selection since the Agricultural Revolution [21, 22]. This period in Africa lasted from about 2.5 million years ago to 11,000 years ago. In fact, most anthropological and genetic studies suggest that all human beings living in Europe, Asia, Oceania, and the Americas share a common African Homo sapiens ancestor [23-25]. It is known that there is less genetic diversity throughout the world's non-African population than there is within Africa itself [22-25]. Several of these selective pressures underlying these post agriculture alleles were not induced by changes in sleep, exercise, and diet but rather by pathogens, fatal diseases, and harsh environments [25-28].

\section{PRIMARY RISK FACTORS OF NON-COMMUNICA- BLE DISEASES}

The evolution of humans from a diet and lifestyle point of view may be divided into four groups, which have different attributes of social classes $[1,5]$ primitive hunter-gatherers, peasant agriculturists and pastoralists, urban slum dwellers, and an affluent society. India is one country which has got all the four types of social groups. There are very few primitive hunter-gatherers in the world today. India, with its approximately 1.22 billion population mainly has farmers, but the rapidly growing towns have an increasing number of poor urban slum dwellers and a big affluent society. Population studies reveal that the levels of physical inactivity, dietary patterns, salt intake, alcohol consumption, tobacco use and stress are important characteristics of various populations [17-21]. Social autopsy studies by verbal autopsy questionnaires indicate that the social determinants of health and behavioral risk factors may be dependent on various attributes of social classes [17-29]. These markers of health can influence behavior and hence these are also called behavioral risk factors, which appear to be primary risk factors of NCDs [18-21].

\section{NUTRITIONAL TRANSITION FROM HOMO SAPIENS TO HOMO ECONOMICUS}

It seems that today, humans live in a nutritional environment which completely differs from that for which our genetic constitution was selected. The food and nutrient intake among hunter-gatherers and during Paleolithic period is given in the Tables 1-5. There is marked reduction in consumption of w-3 fatty acids, antioxidants, vitamins and minerals and proteins and significant increase in the intakes of carbohydrates, ( mainly refined), fat (saturated, trans fat, linoleic acid) and salt compared to Paleolithic period [2-10]. Approximately 10,000 years ago, obviously prior to the Agricultural Revolution and notwithstanding the Neolithic Revolution, sometimes called the Agricultural Revolution concerned with the initial transition from hunter-gather to settled agriculture (BP 10,100), our diet was based on an enormous variety of wild plants. Dietary intakes have changed significantly, during the last 100-160 years causing increased intake of saturated fatty acids (SFA), trans fatty acids and linoleic acid and meat from grain fed cattle, tamed at farm houses, rather than meat from running animals. In general, there is increase in the intake of refined carbohydrates and decrease in the intake of complex carbohydrates, essential amino acids, minerals, w-3 fatty acids, vitamins and antioxidants. These dietary changes in conjunction with sedentary behavior, mental strain, pollution, tobacco consumption and alcoholism, particularly after 1910, during the last 100 years may have caused damage to our genes, leading to emergence of phenotypes of NCDs. There is a greater consumption of pro-atherogenic foods during transition from lower social classes 4-5 (poverty) to higher social classes 1-3 [30-38]. These differences may be associated with differ ences in the food and nutrient intake among hunter-gatherers and among Western and Asian populations during transition from to affluence. Western type diet consumed by lower 
Table 1. Food and Nutrient Intake Among Various Social Groups

\begin{tabular}{|c|c|c|c|}
\hline Food and Nutrient & Hunter-gatherer Society & Western Society & Asian Societies \\
\hline $\begin{array}{l}\text { Energy density } \\
\text { Protein } \\
\text { Animal } \\
\text { Vegetable } \\
\text { Carbohydrate } \\
\text { Fiber } \\
\text { Fat } \\
\text { Animal } \\
\text { Vegetable } \\
\text { Total w-3 } \\
\text { Ratio w-6:w-3 } \\
\text { Vitamins and minerals }\end{array}$ & $\begin{array}{l}\text { Low } \\
\text { High } \\
\text { High } \\
\text { Very low } \\
\text { Low-moderate(slowly ab- } \\
\text { sorbed) } \\
\text { High (>30g) } \\
\text { Low } \\
\text { Low } \\
\text { Very low } \\
\text { High }(2.3 g / \text { day) } \\
\text { Low } 2.4 \\
\text { High }\end{array}$ & $\begin{array}{l}\text { High } \\
\text { Low-moderate } \\
\text { Low -moderate } \\
\text { Low -moderate } \\
\text { Moderate-rapidly absorbed } \\
\text { Low (<15g) } \\
\text { High High } \\
\text { Low (0.2g/day) } \\
\text { High 15-20 } \\
\text { low }\end{array}$ & $\begin{array}{l}\text { Low } \\
\text { Low } \\
\text { Low } \\
\text { Low } \\
\text { High-Slow } \\
\text { High } \\
\text { Low } \\
\text { Low } \\
\text { High } \\
\text { 0.5-0.85g } \\
\text { 25-50 } \\
\text { moderate }\end{array}$ \\
\hline
\end{tabular}

from Eaton et al. [2, 3] and Singh et al. [6] references [1, 10].

Table 2. Estimated Fatty Acid Consumption in the Late Paleolithic Period Social Group

\begin{tabular}{|c|c|}
\hline Sources & Fatty Acids(g/day) en 35.65/Day \\
\hline Linoleic acid & 4.28 \\
\hline \multicolumn{2}{|l|}{ Animal } \\
\hline Linoleic acids & 4.56 \\
\hline \multicolumn{2}{|l|}{ Total } \\
\hline Linoleic acid & 8.84 \\
\hline Alpha linolenic acid & 12.60 \\
\hline \multicolumn{2}{|l|}{ Animal } \\
\hline Arachidonic acid(w-6) (AA) & 1.81 \\
\hline Docosapentaenoic acid(w-3)(DPA) & 0.42 \\
\hline Docosahexaenoic acid(w-3)(DHA) & 0.27 \\
\hline Total long chain w- 3 fatty acids & 1.20 \\
\hline Ratios of w-6/w-3 & 0.70 \\
\hline Linoleic acid/alpha linolenic acid+ & 1.79 \\
\hline $\mathrm{AA}+\mathrm{DTA} / \mathrm{EPA}+\mathrm{DPA}+\mathrm{DHA}$ & \\
\hline Total w-6/w-3 & 0.77 \\
\hline
\end{tabular}

Modified from Eaton et al. [2, 3] and Singh et al. [1, 6].

social classes in the developed countries and higher social classes in developing countries may be associated with marked reductions in the consumption of w-3 fatty acids, vitamins, antioxidants, and amino acids and significant increases in the intakes of carbohydrates, (mainly refined) fat (saturated, trans fat, and linoleic acid), and salt compared to Paleolithic period (Tables 1-5). The protein or amino acid intake was 2.5 fold greater (33 vs. $13 \%$ ) in the Paleolithic diet compared to modern diet (Table 3, Fig. 1). However, today about $17 \%$ of plant species provide $90 \%$ of the world's food supply which is mainly contributed by grains. Recent additions to dietary patterns are cereal grains (refined), and vegetable oils that are rich in w- 6 fatty acids and trans fats and low in amino acids which represent dramatic departure from those foods and nutrients to which we are adapted [13].Wheat, corn and rice account for three quarters of the 
Table 3. Nutrient Composition in the Late Paleolithic Society and Current Recommendations

\begin{tabular}{|l|l|l|}
\hline \multicolumn{1}{|c|}{ Nutrient Per day } & Late Paleolithic Society & Current Recommendation \\
\hline \hline Total dietary energy\% & 33 & 12 \\
Protein & 46 & 38 \\
Carbohydrate & 21 & moderate alcohol \\
Fat & -0 & 1.00 \\
Alcohol & 1.41 & 300 \\
P/S ratio & 520 & $30-60$ \\
Cholesterol, mg & $100-150$ & $1100-3300$ \\
Fiber, g & 690 & $800-1600$ \\
Sodium, mg & $1500-2000$ & 60 \\
Calcium, mg & 440 & \\
Ascorbic acid, mg & & \\
\hline
\end{tabular}

Modified from Eaton et al. [2, 3 their references 1, 2, and Singh et al. [1, 6]

Table 4. Ethnic Differences in Fatty Acid Levels in Thrombocytes Phospholipids and Percentage of All Deaths from Cardiovascular Disease

\begin{tabular}{|l|c|c|c|}
\hline & Europe and USA \% & Japanese Society \% & Greenland Eskimos \% \\
\hline \hline Arachidonic acid(20:4w6) & 26 & 21 & 8.3 \\
Eicosapentaenoic acid(20:5w-3) & 0.5 & 1.6 & 8.0 \\
Ratio of w-6/w-3 & 50 & 12 & 1 \\
Mortality from cardiovascular disease & 45 & 12 & 7 \\
\hline
\end{tabular}

Modified from Singh et al. [1, 6]

Table 5. Fatty Acids Ratio in the Diets of Various Societies

\begin{tabular}{|l|l|l|}
\hline \multicolumn{1}{|c|}{ Subjects } & w-6/w-3 & Estimated \\
\hline \hline Paleolithic & 0.79 & Current 7.10 \\
Greece prior to 1960 & $1.00-2.00$ & Early 1-2 \\
Japan & 4.00 & Prior to 1960, 3-4 \\
India, rural & $5-6.1$ & Prior to 1960, 5-10 \\
India urban & $38-50$ & Prior to 1960,10.00 \\
UK & 15.00 & Prior to 1960,10.00 \\
Northern Europe & 15.00 & Prior to 1950 7-8 \\
USA & 16.74 & Estimated \\
Eastern Europe & $20-25$ & Estimated \\
Indian hunter-gatherers & $1.00-2.00$ & \\
\hline
\end{tabular}

Modified from Singh et al. [1, 6, 10]

world's grain production on which humans are dependent for their food supply. Eaton and co-workers [2, 3, 7] have estimated higher intakes for protein, calcium, potassium and ascorbic acid and a lower intake of sodium in the diet of late Paleolithic period than the current diets of the developed and developing countries. Green leafy vegetables are also rich sources of antioxidants, magnesium, w-3 fatty acids and carotenoids which appear to be high in the Mediterranean region [7-10]. The protective effects of Paleolithic diets in the form of Mediterranean diet, Indo-Mediterranean diet, Japanese diet, and DASH diet have been documented in the several previous studies [1-12]. These diets adopted by Homo economicus, and as such these standards will help evolve Homo modestis, either directly or by epigenetic inheritance or by natural selection (Fabien De Meester, 2011, Personal communication).

\section{SOCIOECONOMIC DETERMINANTS OF HEALTH}

Modern medicine has been giving due consideration to physical health resulting in marked reduction in deaths due to communicable diseases and emergence of morbidity and mortality due to NCDs [15-21]. With increase in income, there is change in diet towards Western type diet and lifestyle characterized with use of automobiles, lack of physical 


\section{The Tsim Tsoum Concept \& Evolutionary Diet}

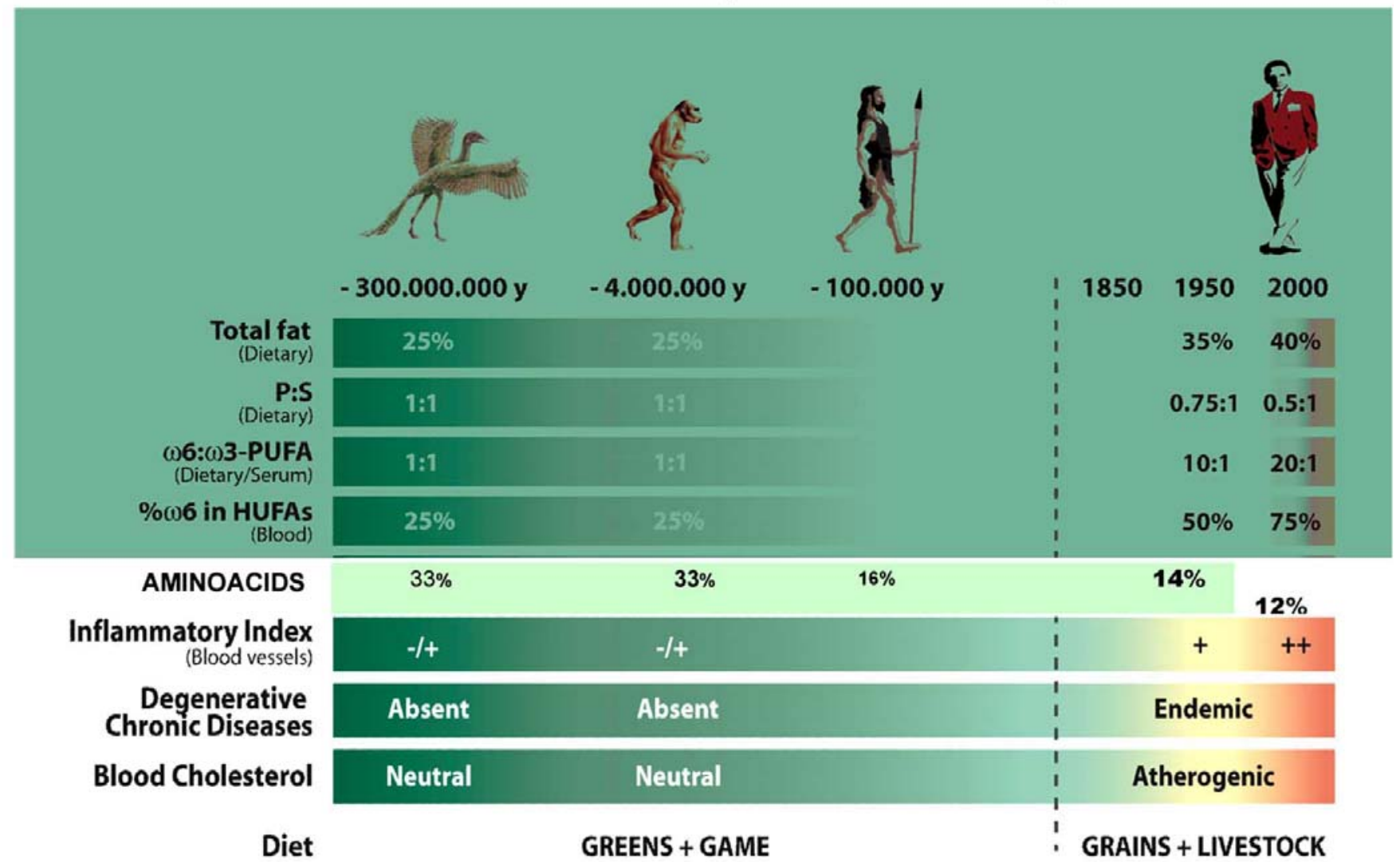

Fig. (1). Nutrient intake among Paleolithic societies; Homo sapiens and Homo economicus.

activity and occupational stress, alcoholism and tobacco consumption [15-21, 30-37]. The main attributes of social classes are; general education and health education, occupation, household income, housing and availability of automobiles, television, car and other luxury items [30-37]. Nutrition health education appears to be most important societal attribute, because knowledge about healthy foods and physical activity can substantially reduce NCDs. In developed countries, consumer durables and housing are important determinants of lifestyle; physical activity, occupational stress and social health [30-37]. These are also important determinants of food consumption patterns, as well as social behavior, which may be societal determinants of health and diseases, and misuse of any substance independently could cause mortality [30-37]. The pathways for development of NCDs are sedentary behavior, excess eating of Western type foods, tobacco use, stress, and alcoholism among individuals and populations with underlying lack of general and health education.

\section{NUTRITION IN TRANSITION AND DIET LINKED CHRONIC DISEASES}

Developing countries, like India, China, Indonesia, Brazil, higher social classes, particularly with an increase in income and greater availability of ready prepared foods, have been observed to have higher risk of NCDs; cardiovascular diseases (CVDs) including coronary artery disease (CAD), stroke, hypertension and type 2 diabetes mellitus [30-36].
However, some experts have disputed that both poverty and wealth may be the primary causes of disability and deaths due to NCDs among Homo economicus populations [16, 17, 39-41].

A recent editorial in the Lancet (Jan 2013) on "Wealth but not health in US" indicates that despite spending more on health care per person than other high-income, affluent democratic countries including Australia, Canada, France, Italy, most of the Nordic countries, Spain, and the UK, life expectancy is shorter at birth for American men than for men in any of the other 16 countries, and American women fare little better. In nine key areas of health; infant mortality and low birth weight; injuries and homicides; teenage pregnancies and sexually transmitted infections; HIV/AIDS prevalence; drug-related deaths; obesity and diabetes; heart disease; chronic lung disease; and disability, Americans fare least well, or are near the bottom of the tables. This disadvantage in health applies to those with health insurance, a college education, higher incomes and healthy behaviors as well as to those without. However, those Americans who reach 75 years live longer than their peers in other countries, and that Americans have low death rates from stroke and cancer. The current smoking rates are low, which should lead to future health benefits and household income is relatively high. US health spending was US\$2.7 trillion in 2011, which is $\$ 8700$ for every person in the country, and represents $17 \cdot 9 \%$ of the economy. This is far greater than any other economically advanced country. Unfortunately, spending on 
health care bears little relation to good health. It is not absolutely clear why Americans are at a health disadvantage compared with those in other countries. Lack of insurance, or inadequate insurance, restricts access to health care for many Americans and, in particular, poor access to health care and to primary care, are partly to blame. Apart from the system, unhealthy behaviors abound in the USA, particularly overeating, drug abuse, and other risk-taking activities such as not wearing motorcycle helmets, drinking and driving, and using firearms. There is a great disparity in social and economic conditions and standard of education in the USA which contribute to high incomes for some, but to high poverty and income inequality for others $[16,17]$.

A recent study examines the association of social class and wealth as risk factors for deaths due to NCDs [33]. Randomly selected death records of 2,222 (1,385 men and 837 women) decedents, aged 25-64 years at time of death were studied. Social classes were assessed, based on attributes of per capita income, occupation, education, housing, and ownership of consumer luxury items in the household. Poverty was considered if the total family income was <US\$300per month. Lack of knowledge on health education about the role of exercise, prudent diet, and adverse effects of tobacco use and alcoholism was studied by the validated questionnaires [33]. This study showed that sedentary behavior, excess salt intake, and other typical Western dietary habits were significantly more common among decedents belonging to higher social classes 1-3, compared to those within lower social classes 4 and 5 . Lack of knowledge regarding health education was significantly more common among decedents in lower social classes, who died more often due to communicable diseases. The study also revealed that deaths associated with diabetes mellitus and due to circulatory diseases were significantly more common among higher social classes 1-3, compared to lower social classes 4 and 5. However, deaths due to malignant diseases and chronic lung diseases were not associated with social class (except the social class of women with breast cancer), but total proportion of deaths due to NCDs including these causes were significantly greater among higher social classes 1-3, compared to lower social classes 4 and 5 . The findings indicate that sedentary behavior, typical Western diet, and excessive salt intake, in conjunction with underlying lack of health education, may be the predisposing factors for deaths among decedents of higher social classes 1-3. Among lower social classes 4 and 5, general lack of health education may have caused more deaths due to communicable diseases, as well as injury and accidents. This study shows that lack of health education appears to be the major cause of deaths due to circulatory diseases and diabetes mellitus among higher social classes 1-3, whereas among lower social classes, this may be the underlying cause of deaths due to communicable diseases. Malignant diseases and chronic lung diseases were common among all social classes. It is clear that knowledge about health education on diet and lifestyle appears to be most important attribute which should be assessed to determine social class of the subjects and the population.

A case control study [41] of 11119 patients with a first myocardial infarction and 13648 age matched (up to 5 years older or younger) and sex-matched controls from 262 centres in Asia, Europe, the Middle East, Africa, Australia, and North and South America was undertaken. Subjects with myocardial infarction (cases) reported higher prevalence of all four stress factors $(\mathrm{p}<0 \cdot 0001)$. Of those cases still working, $23 \cdot 0 \%(n=1249)$ experienced several periods of work stress compared with $17 \cdot 9 \%$ (1324) of controls, and $10 \cdot 0 \%$ (540) experienced permanent work stress during the previous year versus $5 \cdot 0 \%$ (372) of controls. After adjustment for age, sex, geographic region, and smoking, odds ratios were $1 \cdot 38$ (99\% CI $1 \cdot 19-1 \cdot 61)$ for several periods of work stress and $2 \cdot 14(1 \cdot 73-2 \cdot 64)$ for permanent stress at work,11·6\% (1288) of cases had several periods of stress at home compared with $8.6 \%$ (1179) of controls (odds ratio 1.52 [99\% CI $1 \cdot 34$ $1 \cdot 72]$ ), and $3 \cdot 5 \%$ (384) of cases reported permanent stress at home versus $1 \cdot 9 \%$ (253) of controls $(2 \cdot 12$ [1·68-2·65]). General stress (work, home, or both) was associated with an odds ratio of $1 \cdot 45(99 \%$ CI $1 \cdot 30-1 \cdot 61)$ for several periods and $2 \cdot 17(1 \cdot 84-2 \cdot 55)$ for permanent stress. Severe financial stress was more typical in cases than controls (14.6\% [1622] vs. $12 \cdot 2 \%$ [1659]; odds ratio $1 \cdot 33$ [99\% CI $1 \cdot 19-1 \cdot 48]$ ). Stressful life events in the past year were also more frequent in cases than controls (16.1\% [1790] vs. $13 \cdot 0 \%$ [1771]; $1 \cdot 48$ $[1 \cdot 33-1 \cdot 64])$, as was depression $(24 \cdot 0 \%$ [2673] vs. $17 \cdot 6 \%$ [2404]; odds ratio $1 \cdot 55$ [1.42-1.69]). It is clear that the presence of psychosocial stressors was associated with increased risk of acute myocardial infarction, suggesting that new approaches aimed at modifying social and mental health as well as health behavior, should be developed for prevention of CVDs.

In high income countries, lower social classes 3 and 4 have poor health behavior and greater risk factors of cardiovascular and cancer mortality, as well as all-cause mortality than higher social classes [16, 17, 37-41]. The higher social classes ( 1 and 2 ) appear to have greater access to health education, spare time to increase physical activity and additional resources to maintain prudent diets than lower social classes in the developed countries. This situation is in contrast to lower social class 3-5, in developing countries, who are living with a scarcity of foods and irregular employment. Physically demanding occupations are common in developing countries, but do not exist in developed countries, where they have only social classes 1-4 [18-21, 30-41]. It seems that in developing societies, urban populations have a double burden of diseases, related to overeating as well as malnutrition because occupational physical activity decreases along with change in social class [30-35].

Popkin has also agreed with the above global nutrition dynamics in which the world is shifting rapidly toward a diet linked with NCDs [42] ( Table 6).The role of fatty acids, essential and non-essential amino acids, antioxidants and vitamins in the prevention and pathogenesis of CVDs, type 2 diabetes and insulin resistance are well known [43-45]. Humans appear to live in a nutritional environment which completely differs from that for which our genetic constitution was selected [19-29]. The role of a low w-6/w-3 ratio Paleolithic type of diet by increasing $w-3$ and by decreasing $w-6$ fatty acid in the Paleolithic style diet can cause significant decline in cardiovascular and all cause Fig. (2)]. In this randomized, controlled trial, the experimental group received 
Table 6. Nutrition in Transition and Emergence of Non-communicable Diseases

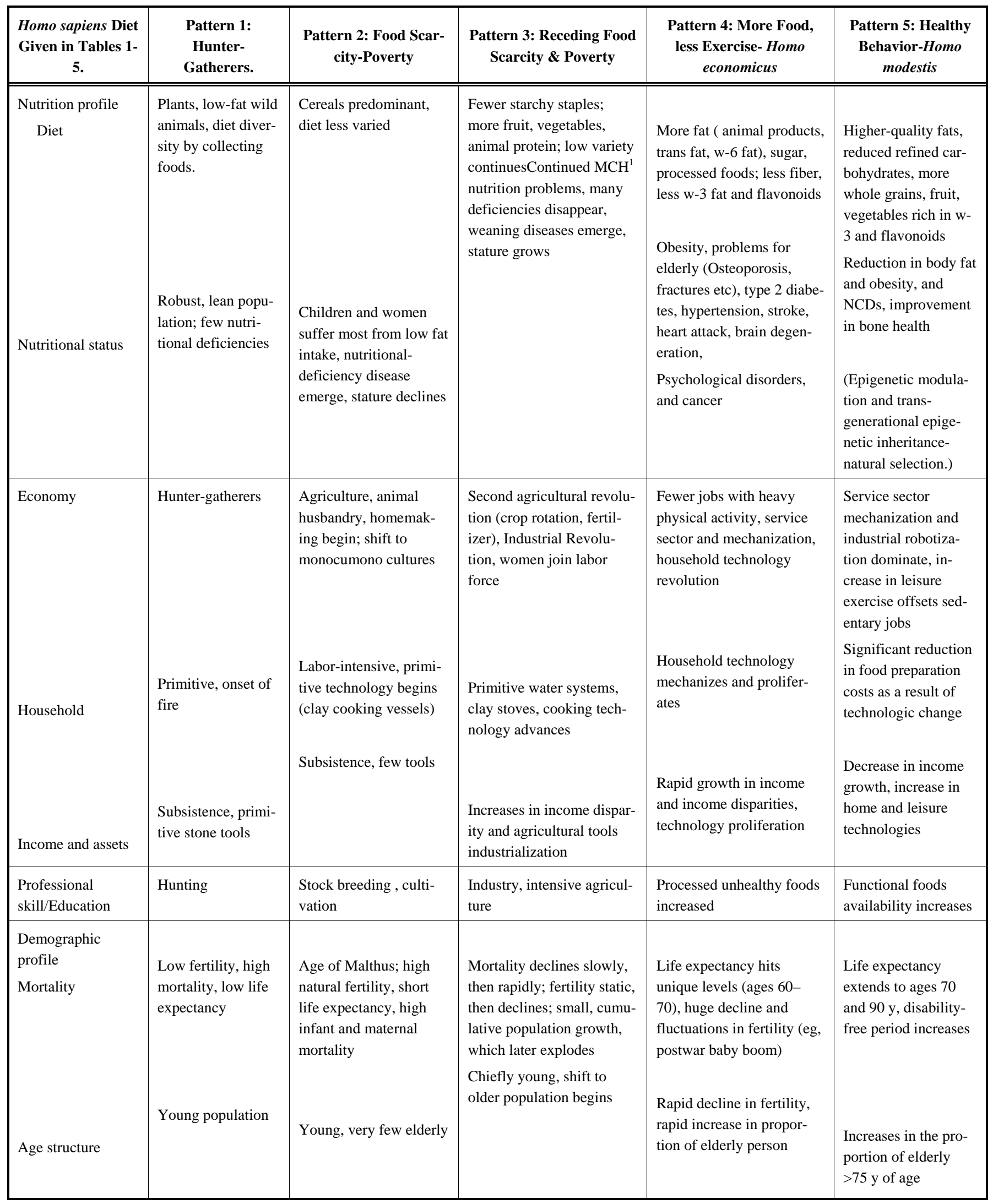


Table 6. Contd.....

\begin{tabular}{|l|l|l|l|l|l|}
\hline $\begin{array}{c}\text { Homo sapiens Diet } \\
\text { Given in Tables 1- } \\
\text { 5. }\end{array}$ & $\begin{array}{c}\text { Pattern 1: } \\
\text { Hunter- } \\
\text { Gatherers. }\end{array}$ & $\begin{array}{c}\text { Pattern 2: Food Scar- } \\
\text { city-Poverty }\end{array}$ & $\begin{array}{c}\text { Pattern 3: Receding Food } \\
\text { Scarcity \& Poverty }\end{array}$ & $\begin{array}{c}\text { Pattern 4: More Food, } \\
\text { less Exercise- Homo } \\
\text { economicus }\end{array}$ & $\begin{array}{c}\text { Pattern 5: Healthy } \\
\text { Behavior-Homo } \\
\text { modestis }\end{array}$ \\
\hline \hline Housing & Rural, low density & $\begin{array}{l}\text { Rural, a few small, } \\
\text { crowded cities } \\
\text { Food storage begins }\end{array}$ & $\begin{array}{l}\text { Chiefly rural, move to } \\
\text { cities increases, interna- } \\
\text { tional migration begins, } \\
\text { megacities develop }\end{array}$ & $\begin{array}{l}\text { Dispersal of urban popula- } \\
\text { tion decrease in rural green } \\
\text { space }\end{array}$ & $\begin{array}{l}\text { Lower-density cities } \\
\text { rejuvenate, increase } \\
\text { in urbanization of } \\
\text { rural areas encircling } \\
\text { cities }\end{array}$ \\
& Nonexistent & None & $\begin{array}{l}\text { Storage processes (drying, } \\
\text { salting) begin, canning and } \\
\text { processing technologies } \\
\text { emerge, increases in food } \\
\text { refining and milling }\end{array}$ & $\begin{array}{l}\text { Numerous food- trans- } \\
\text { forming technologies }\end{array}$ & $\begin{array}{l}\text { Technologies create } \\
\text { functional foods and } \\
\text { food constituent } \\
\text { substitutes (ie, } \\
\text { macronutrient substi- } \\
\text { tutes) }\end{array}$ \\
\hline
\end{tabular}

${ }^{1}$ MCH, maternal and child health, modified from Popkin 2006, References [20, 38, 42]

significantly greater amount of fruits, vegetables and whole grains, nuts and mustard oil and lower clarified butter compared to control diet group at one year of follow up [45]. Total adherence score to Paleolithic style diet and prudent diet were significant in both the groups. Omega-6/Omega-3 fatty acid ratio of the diet which was much higher before entry to the study (32.5 \pm 3.3$)$, was brought down to significantly lower content in the Paleolithic style diet group A ( $\mathrm{n}=$ 204, compared to control group diet $B(n=202)$ at entry to the study ( $3.5 \pm 0.76$ vs. $24.0 \pm 2.4 \mathrm{KJ} /$ day, $\mathrm{p}<0.001$ ). The fatty acid ratio remained significantly much lower in the experimental group compared to control group after one year of follow up ( $4.4 \pm 0.56$ vs. $22.3 \pm 2.1, \mathrm{KJ} /$ day, $\mathrm{p}<0.001)$. Total mortality was $14.7 \%$ in the Paleolithic style diet group and $25.2 \%$ in the control group, after a follow up of two years. The association $w-6 / w-3$ ratio of fatty acids with mortality showed a gradient in both the groups independently, as well as among total number of deaths. A lower w-6/w-3 ratio of fatty acids from 1-10 was associated with a significantly lower mortality whereas increase in $w-6 / w-3$ fatty acid ratio to more than 10 was associated with greater mortality (Fig. (2), Tables 7-9).

In the 1950s Halberg's group demonstrated that eating moderate breakfast in the morning may have less increase in body weight compared to same amount for dinner [46]. This observation is quite important for developing societies who were under-nutrition in 1950s after World War II, but eating a larger breakfast comprising of 1000 calories, may result into circadian increase in cardiovascular events in between $6.00-1200$ hours among societies with overnutrition such as in affluent societies now [47]. It would be pertinent to select functional foods for the breakfast comprising of about $500 \mathrm{~K}$ Cal to have the beneficial effects of functional nutrients as well as of increased energy metabolism in the morning as advised by Halberg et al, causing no increase in body weight

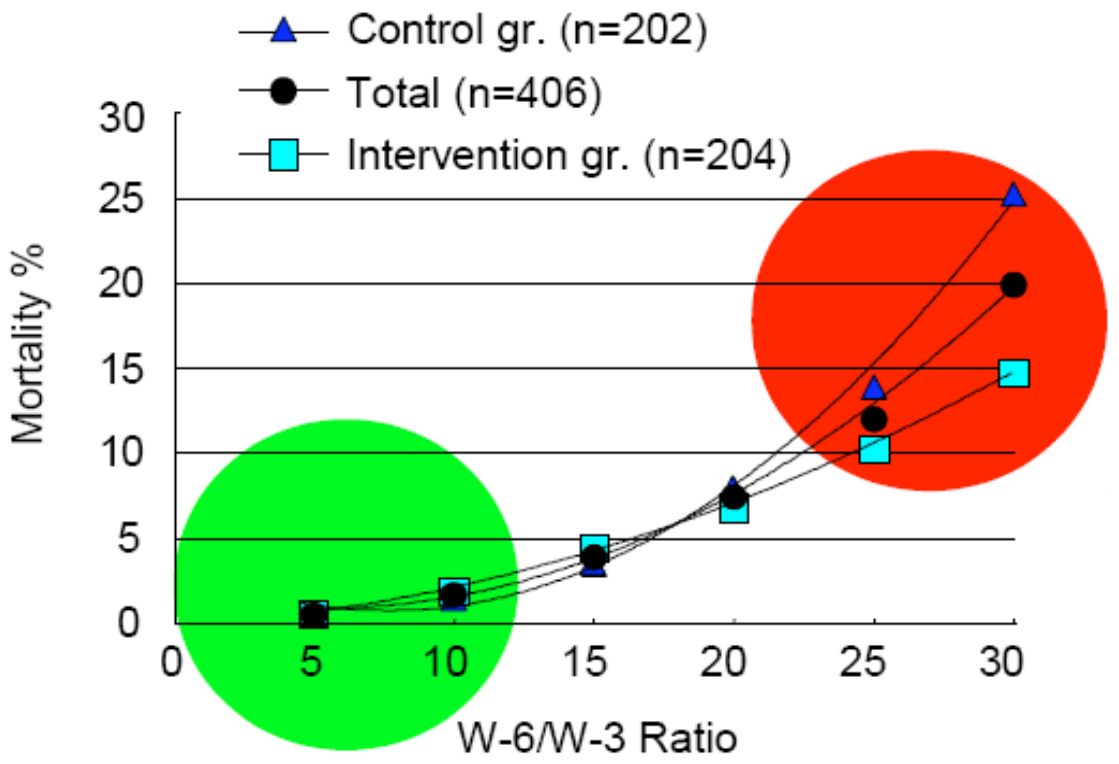

Fig. (2). Effect of low w-6/w-3 fatty acid ratio diet on mortality (Reference 35, Singh et al). 


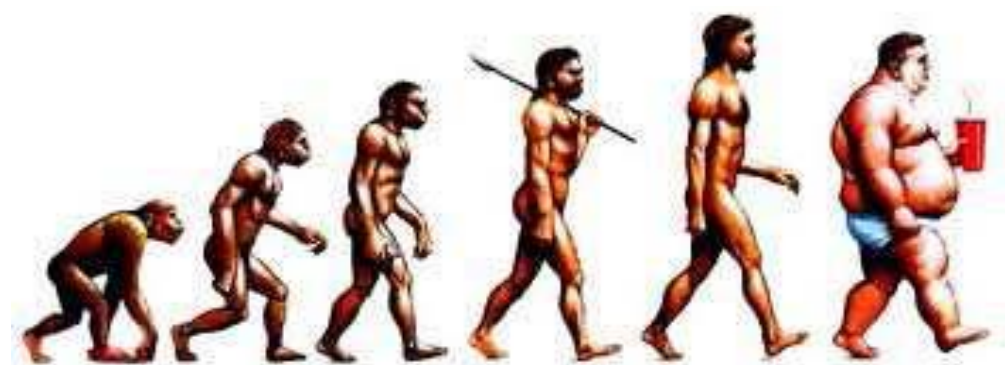

Fig. (3). Effects of diet and lifestyle on body composition from Homo sapiens to Homo erectus and modern man- Homo economicus, in indicating body mind index(Fabien De Meester 2013).

Table 7. Effect of w-3 fatty Acid Rich Paleolithic Style Diet in Patients with Acute Myocardial Infarction

\begin{tabular}{|c|c|c|c|c|}
\hline \multirow[b]{2}{*}{ Foods and nutrients } & \multicolumn{2}{|c|}{ Paleolithic Style Diet Group $(n=204)$} & \multicolumn{2}{|c|}{ Standard Diet Group $(n=202)$} \\
\hline & 4-7 days & After 1 years & 4-7 days & After 1 years \\
\hline Fruits and vegetables (g. day-1) & $508.4(28.66) *$ & $575(91.4) * *$ & $254.4(17.2)$ & $220.5(19.6)$ \\
\hline Legumes and pulses (g. Day-1) & $80.5(6.6) * *$ & $95.0(8.9) * *$ & $52.5(4.6)$ & $45.6(5.6)$ \\
\hline Almonds and walnuts (g. Day-1) & $82.4(5.7) * *$ & $75.5(5.2) * *$ & - & - \\
\hline Chicken (g. Day-1) & - & $10.2(3.2)^{*}$ & $76.2(6.5)$ & $66.5(10.5)$ \\
\hline Mustard or soybean oil & $18.4(3.9)^{*}$ & $31.5(5.5) * *$ & $10.5(2.3)$ & $6.8(2.8)$ \\
\hline Butter or clarified butter (g. Day-1) & $2.5(0.6) * *$ & $3.3(0.71)^{*}$ & $10.5(2.6)$ & $12.6(3.5)$ \\
\hline Skim milk (ml day-1) & $161.2(12.0)$ & $152(14.5)^{*}$ & $150.2(8.0)$ & $165.5(16.1)$ \\
\hline Wheat chapatti & $5.5(1.6) * *$ & $30.6(5.5)$ & $50.6(6.6)$ & $55.6(7.8)$ \\
\hline Sugar (g. Day-1) & $16.4(3.7)^{*}$ & $12.6(3.4)^{*}$ & $25.5(5.4)$ & $30.5(7.6)$ \\
\hline ----------------------------------------- & ---------------- & |------------ & |------------- & |------------- \\
\hline Total Adherence score (\%) & $65.2(17.2)$ & 63.9(14.8) & $123.0(30.0)$ & $71.0(30.0)$ \\
\hline Total foods, & 1027(232) & 1184.6(254) & 983.4(213) & $862(204)$ \\
\hline
\end{tabular}

$\mathrm{P}$ values for mean (standard deviation) were obtained by comparison of intervention and control groups after 1 week, and after 1 year. ${ }^{*}=\mathrm{P}<0.05$, ${ }^{* *} \mathrm{P}<0.01$, Singh et al. (45) their reference [40].

Table 8. Fatty Acid Consumption in the Paleolithic Style Diet Group and Standard Diet Group

\begin{tabular}{|c|c|c|c|c|c|}
\hline \multicolumn{3}{|r|}{ Before entry } & \multicolumn{2}{|c|}{ At entry } & After one year \\
\hline Fatty acid $\mathrm{KJ} /$ day & All patients $(n=406)$ & Paleolithic $(n=204)$ & Standard $(n=202)$ & Paleolithic $(n=204)$ & Standard (n-202) \\
\hline Saturated & $10.0(0.39)$ & $7.0(0.22)$ & $10.0(0.38)$ & $7.2(0.24)$ & $10.8(0.36)$ \\
\hline Monounsaturated & $9.3(0.38)$ & $9.5(0.37)$ & $7.6(0.26)$ & $8.0(0.35)$ & $10.2(0.32)$ \\
\hline Polyunsaturated & $6.7(0.30)$ & $8.1(0.44)$ & $6.5(0.39)$ & 8.6(0.39) & $7.0(0.26)$ \\
\hline $\mathrm{W}-6$ & $6.5(0.29)$ & $6.3(0.28)$ & $6.3(0.29)$ & $7.0(0.36)$ & $6.2(0.24)$ \\
\hline $\mathrm{W}-3$ & $0.2(0.07)$ & $1.8(0.13)^{* *}$ & $0.2(0.082)$ & $1.6(0.12)^{* *}$ & $0.3(0.083)$ \\
\hline W-6/W-3 ratio & $32.5(3.3)^{* *}$ & $3.5(0.76)^{* *}$ & $31.5(2.4)$ & $4.4(0.56)^{* *}$ & $20.6(2.1)$ \\
\hline Main dietary oil & Peanut & Mustard & Sunflower & Mustard & Sunflower \\
\hline
\end{tabular}

Values are mean \pm Standard deviation ${ }^{* *}=\mathrm{p}<0.01$, Singh et al. 2012 [45], their reference [40].

compared to same amount of energy in the evening [45-50]. Diet can also influence brain-liver and heart connection leading to NCDs [51, 52]. However, an Indo-Mediterranean diet and other nitric oxide activating foods may be protective against CVDs as well as other NCDs (Table 10) [53, 54].
Adverse effects of Tamasic foods characteristics of the Western diet were also proposed by Indian ancient physicians; Charak and Sushruta in 600 BCE as well as by Confucius in China (500BCE) and by the Greek physician Hippocrates (500BCE) who proposed lets “ FOOD BE OUR 
Table 9. Numbers and Rate Ratios for End Points in the Paleolithic Style Diet Group and Standard Diet Group after 2 Years of Follow Up

\begin{tabular}{|l|c|c|c|}
\hline \multicolumn{1}{|c|}{ Events } & Paleolithic Style Diet(n=204) & Control Diet (n=202) & Adjusted Rate Ratio (95\% Confidence interval) \\
\hline \hline Total Cardiac mortality & $27(13.2)^{* *}$ & $45(22.3)$ & $0.59(0.52-0.67)$ \\
\hline Fatal myocardial infarction & $18(8.8)^{* *}$ & $27(13.3)$ & $0.66(0.61-0.73)$ \\
\hline Sudden cardiac death & $9(4.4)^{*}$ & $18(8.9)$ & $0.50(0.38-0.73)$ \\
\hline $\begin{array}{l}\text { Total cardiovascular mortal- } \\
\text { ity }\end{array}$ & $30(14.7)^{* *}$ & $50(24.7)$ & $0.50(0.42-0.59)$ \\
\hline Total mortality & $30(14.7)^{* *}$ & $51(25.2)$ & $0.59(0.51-0.67)$ \\
\hline
\end{tabular}
and blood pressure.

Table 10. Total Cardiovascular Events in the Paleolithic Style Diet and Control Group

\begin{tabular}{|l|c|c|}
\hline \multicolumn{1}{|c|}{ Data } & Indo-Mediterranean Diet (n=499) & Standard Diet (n=501) \\
\hline Non fatal myocardial infarction & $21(4.2 \%)^{*}$ & $43(8.6 \%)$ \\
Fatal myocardial infarction & $12(2.4 \%)$ & $17(3.4 \%)$ \\
Sudden cardiac death & $6(1.2 \%)$ & $16(3.2 \%)$ \\
Total cardiac events & $39(7.8 \%)^{* *}$ & $76(15.2 \%)$ \\
Stroke & $7(1.4 \%)$ & $13(2.6 \%)$ \\
Stroke death & $2(0.4 \%)$ & $3(0.6 \%)$ \\
Total cardiovascular events & $48(9.6 \%)^{* *}$ & $92(18.3 \%)$ \\
Total deaths & $24(4.8 \%)$ & $38(8 \%)$ \\
\hline
\end{tabular}

Values are number (\%), ${ }^{*}=\mathrm{P}<0.01,{ }^{* *}=\mathrm{P}<0.001$, Singh et al., 2002 [53] their references [35].

MEDICINE “[49, 50]. Around 5000 years ago, Indians were aware of the harmful effects of dietary ingredients which are evident from ancient scripture of the Bhagwata Gita (3100 BC).

Some experts (FD) from have proposed "Mind, Body Index= BMI" to address total health because physical, social, mental and spiritual health may depend on body composition. It is remarkable that animals including man in the wild do not suffer overweight. Even modern husbandry animals don't. In contrast, companion pets may and societal man does. The human part - the mind - appears responsible for the disease (Fig. 3). It is important to analyze facts as primary and secondary risk factors. Food is here secondary. It contributes, yet does not cause the problem. Just as cholesterol contributes, but does not cause heart disease (www.columbus-concept.com). Once understood and accepted, such basic principle allows one to take the right decision. This is an important explanation of why in the United States, there is wealth, but only limited health [16].

In brief, food consumption patterns and health behavior have changed significantly in various societies, during transition from Homo sapiens to Homo economicus populations. The nutritional transition has been quite rapid during the last 100-160 years, causing increased intake of saturated fatty acids (SFA), trans fat, refined carbohydrates and linoleic acid, and decreased w-3 fatty acids and flavonoids, from grain-fed cattle, tamed at farm houses, rather than meat from running animals, resulting in marked increase in morbidity and mortality due to NCDs. The population characteristics, such as dietary intakes, in conjunction with sedentary behavior appear to be the main causes of poor social, mental and spiritual health as well as of hyperlipidemia, hyperglycemia, oxidative stress and inflammation which are important mechanisms in the pathogenesis and prevention of dietrelated NCDs [40-44]. What is needed now through education and 'indoctrination, is a cultural change of families to take heed of advice on dietary intervention/prevention of NCDs that gives each generation healthier outcomes, a reduced health burden to individual and state, and even a world unification on this issue - a Human World Army as proposed by The Tsim Tsoum Institute at the $6^{\text {th }}$ World Congress of Clinical Nutrition in Delhi in 2011,

\section{COIFLICT OF INTERESTS}

Conflict of interest has not been declared by the authors.

\section{ACKNOWLEDGEMENTS}

The International College of Nutrition and International College of Cardiology are thanked for supporting this study.

\section{REFERENCES}

[1] Singh RB, Reddy KK, Fedacko J, De Meester F, Wilczynska A, Wilson DW. Ancient concepts in nutrition and diets in huntergatherers. Open Nutraceuticals J 2011; 4: 130-5.

[2] Eaton SB, Konner M, Shostak M. Stone agers in the fast lane: chronic degenerative diseases in evolutionary perspective. Am J Med 1988; 84: 739-49.

[3] Eaton SB, Konner M. Paleolithic nutrition. A consideration of its nature and current implications. N Engl J Med 1985; 312(5): 283-9.

[4] Lannan CR. Har Loomis WF. Skin pigment regulation of vitamin D biosynthesis in man. Science 1967; 157: 5016.

[5] Lindeberg S. Food and Western Disease: Health and Nutrition from an Evolutionary Perspective. Chichester, UK: Wiley-Blackwell 2010. 
[6] Singh RB, De Meester F, Wilczynska A. The Tsim Tsoum approaches for prevention of cardiovascular diseases. Cardiol Res Pract 2010; 2010: 18.

[7] Eaton SB, Eaton SB III, Sinclair AJ, Cordain I, Mann NJ. Dietary intake of long chain polyunsaturated fatty acids during the Paleolithic period. In: Simopoulos AP, Ed. The return of w-3 fattyacids in the food supply. Land based Animal Food Products and their Health Effects. Basel Karger: World Rev Nutr Dietetics 1998; vol 83, pp. 12-23.

[8] Carrera-Bastos P, Fintess-Villaba M, O’Keefe JH, Lindeberg S, Cordain L. The Western diet and lifestyle and diseases of civilization. Res Rep Clin Cardiol 2011; 2: 15-35.

[9] Singh RB, Moshiri M, De Meester F, Juneja L, Muthusamy V, Manoharan S. The evolution of low w-6/w-3 ratio dietary pattern and risk of cardiovascular diseases and diabetes. J Altern Med Res 2011; 3: 45-57.

[10] De Meester F. Wild-type land based foods in health promotion and disease prevention: the LDL-CC:HDL-CC model. In: DeMeester F, Watson RR. Eds. Wild Type Foods in Health Promotion and Disease Prevention. NJ: Humana Press 2008; pp. 3-20.

[11] Esposito K, Glugliano D. Diet and inflammation: a link to metabolic and cardiovascular diseases. Eur Heart J 2006; 27: 15-20.

[12] Katcher HI, Legro RS, Kunselman AR, et al. The effects of whole grain- enriched hypocaloric diet on cardiovascular disease risk factors in men and women with metabolic syndrome. Am J Clin Nutr 2008; 87: 79-90.

[13] Fung TT, Malik V, Rexroad KM, Manson JE, Willett WC, Hu FB. Sweetened beverage consumption and risk of coronary heart in women. Am J Clin Nutr 2009; 89: 1037-42.

[14] De Meester F. Progress in lipid nutrition: the Columbus concept addressing chronic diseases. World Rev Nutr Diet 2009; 100: 11021.

[15] Marmot M, Allen J, Bell R, Bloomer E, Goldblatt P. Consortium for the European Review of Social determinants of Health and the Health Divide. WHO European review of social determinants of health and the health divide. The Lancet 2012; 380: 1011-29.

[16] Editorial. Wealth but not health in USA. Lancet 2013; 381: 177.

[17] Singh RB, De Meester F, Wilson DW. Globalization of wealth but not health in the world. (Under consideration)

[18] Pettee KK, Ainsworth BE. The Building Healthy Lifestyles Conference: modifying lifestyles to enhance physical activity, diet, and reduce cardiovascular disease. Am J Lifestyle Med 2009; 3(1 Suppl): 6s-10s.

[19] Frassetto LA, Schloetter M, Mietus-Synder M, et al. Metabolic and physiologic improvements from consuming a paleolithic, hunter gatherer type diet. Eur J Clin Nutr 2009; 63(8): 947-55.

[20] Lindeberg S. Food and Western Disease: Health and Nutrition from an Evolutionary Perspective. Chichester, UK: Wiley-Blackwell 2010.

[21] Carrera-Bastos P, Fintess-Villaba M, O’Keefe JH, Lindeberg S, Cordain L. The Western diet and lifestyle and diseases of civilization. Res Rep Clin Cardiol 2011; 2: 15-35.

[22] Pritchard JK. How we are evolving. Sci Am 2010; 303(4): 40-7.

[23] White TD, Asfaw B, DeGusta D, et al. Pleistocene Homo sapiens from Middle Awash, Ethiopia. Nature 2003; 423(6941): 742-7.

[24] McDougall I, Brown FH, Fleagle JG. Stratigraphic placement and age of modern humans from Kibish, Ethiopia. Nature 2005; 433: 733-6.

[25] Manica A, Amos W, Balloux F, Hanihara T. The effect of ancient population bottlenecks on human phenotypic variation. Nature 2007; 448(7151): 346-8.

[26] Wang ET, Kodama G, Baldi P, Moyzis RK. Global landscape of recent inferred Darwinian selection for Homo sapiens. Proc Natl Acad Sci U S A 2006; 103(1): 135-40.

[27] Voight BF, Kudaravalli S, Wen X, Pritchard JK. A map of recent positive selection in the human genome. PLoS Biol 2006; 4(3): e72.

[28] Pollard KS, Salama SR, Lambert N, et al. An RNA gene expressed during cortical development evolved rapidly in humans. Nature 2006; 443(7108): 167-72.

[29] Luca F, Perry GH, Di Rienzo A. Evolutionary adaptations to dietary changes. Annu Rev Nutr 2010; 30: 291-314.

[30] Singh RB, Singh V, Kulshrestha SK, et al. Social class and all cause mortality in an urban population of north India. Acta Cardiol 2005; 60: 611-7.
[31] Singh RB, Fedacko J, Vargova V, et al. Singh's verbal autopsy questionnaire for assessment of causes of death, social autopsy, tobacco autopsy, and dietary autopsy based on medical records and interview. Acta Cardiol 2011; 66: 471-81.

[32] Singh RB, Ghosh S, Niaz MA, Rastogi V. Validation of physical activity and socioeconomic questionnaire in relation to food intakes for the five city study and a proposed classification for Indians. J Assoc Phys India 1997; 45: 603-7.

[33] Singh RB, Anjum B, Takahashi T, et al. Poverty is the absolute cause of deaths due to noncommunicable diseases. World Heart $\mathrm{J}$ 2012; V4 (2-3) (in press).

[34] Singh RB, Beegom R, Mehta AS, et al. Social class, coronary risk factors and undernutrition, a double burden of diseases, in women during transition, in five Indian cities. Int J Cardiol 1999; 69: 13947.

[35] Singh RB, Sharma JP, Rasogi V, et al. Social class and coronary disease in a rural population of north India. Eur Heart J 1997; 18: 588-95.

[36] Pednekar MS, Gupta R, Gupta PC. Illiteracy, low educational status and cardiovascular mortality in India. BMC Public Health 2011; 11: 567.

[37] Teo K, Chow CK, Vaz M, Rangarajan S, Yusuf S. The Prospective Urban Rural Epidemiology (PURE) study: examining the impact of societal influences on chronic noncommunicable diseases in low, middle, and high-income countries. Am Heart J 2009; 158: 1-7.

[38] Gillum RF. The epidemiological evolution in pattern of cardiovascular diseases in blacks. N Engl J Med 1996; 335: 1597-9.

[39] Kesteloot H. Social class, all cause and cardiovascular mortality. Acta Cardiol 2004; 59: 117.

[40] WHO. Mortality and burden of disease estimates for WHO Member States in 2008. Geneva: World Health Organization 2010.

[41] Rosengren A, Hawken S, Ounpuu S, et al. Association of psychosocial risk factors with risk of acute myocardial infarction in 11119 cases, 13648 controls from 52 countries (the INTERHEART Study): case control study. Lancet 2004; 364: 937-52.

[42] Popkin BM. Global nutrition dynamics; the world is shifting rapidly toward a diet linked with noncommunicable diseases. Am J Clin Nutr 2006; 83: 289-98.

[43] Simopoulos AP. Evolutionary aspects of the dietary omega6/omega-3 fatty acid ratio: medical implications. In: Simopoulos AP, De Meester F, Eds. A Balanced Omega-6/Omega-3 Fatty acid Ratio. Cholesterol and Coronary Heart Disease. Basel, Karger: World Rev Nutr Diet 2009; vol 100: pp. 1-21.

[44] Singh RB, DeMeester F, Mechirova V, Pella D, Otsuka K. Fatty acids in the causation and therapy of metabolic syndrome. In: De Meester F, Watson RR, Eds. Wild type foods in health promotion and disease prevention. NJ: Humana Press 2008; pp. 263-84.

[45] Singh RB, Fedacko J, Vargova V, Pella D, Niaz MA, Ghosh S. Effect of Low W-6/W-3 Fatty Acid Ratio Paleolithic Style Diet in Patients with Acute Coronary Syndromes: A Randomized, Single Blind, Controlled Trial. World Heart J 2012; 4: 71-84.

[46] Cornelissen G. When you eat matters: 60 years of Franz Halberg's nutrition chronomics. Open Nutraceuticals J 2012; 5(Suppl): 16-44.

[47] Singh RB, Singh AK, Sharma JP, et al. Nutrition in Chronocardiology: We are Indebted Professor Franz Halberg. Open Nutraceuticals J 2012; 5(Suppl): 45-65.

[48] Toda E, Toru T, Singh RB, Alam SE, et al. Can low w-6/w-3 ratio Paleolithic style diet stop cardiovascular diseases? Tissue is the Issue. Am Med J 2012; 3: 183-93.

[49] Charaka S. (Charka, 600 BC). Varanasi, Delhi: Chaukhambha Orientalia, 1981, [Translated by Sharma PV], Harvard Oriental Series. Motilal Banarsidass, Delhi, 1984.

[50] Sushruta S. (Sushruta, 600 BC), vol. 1-3, Varanasi: Sanskrit Series Office, 1999, [Translated by Bhisagratna Chaukhambha], Varanasi 1984.

[51] Wang PY, Caspi L, Lam CK, et al. Upper intestinal lipids trigger a gut-brain-liver axis to regulate glucose production. Nature 2008; 452: 1012-6.

[52] Singh RB, De Meester F, Wilczynska A, Wilson DW, Hungin APS. The liver-pancreas and brain connection in the pathogenesis of obesity and diabetes mellitus. World Heart J 2010; 2: 319-26.

[53] Singh RB, Dubnov G, Niaz MA, et al. Effect of an IndoMediterranean diet on progression of coronary disease in high risk patients: a randomized single blind trial. Lancet 2002; 360: 145561. 
[54] Hristova K, Nakaoka T, Otsuka K, Fedacko J, Singh R, Singh RB, De Meester F, Wilczynska A, Wilson DW.Perspectives on Choco- late Consumption and Risk of Cardiovascular Dis-eases and Cognitive Function. Open Nutraceuticals J 2012, 5, 207-12.

Received: February 12, 2013

Revised: February 14, 2013

Accepted: February 14, 2013

(C) Singh et al.; Licensee Bentham Open.

This is an open access article licensed under the terms of the Creative Commons Attribution Non-Commercial License (http://creativecommons.org/licenses/by-nc/3.0/) which permits unrestricted, non-commercial use, distribution and reproduction in any medium, provided the work is properly cited. 